Historic, Archive Document

Do not assume content reflects current scientific knowledge, policies, or practices. 

$A$ List of Plants

Especially Adapted

\title{
to the South
}

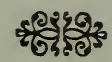 \\ Grown BY \\ JUNGLE GARDENS, INC. \\ AVERY ISLAND, LOUISIANA
}

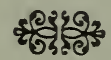

Holding Membership In

American Association of Nurserymen

Southwestern Association of Nurserymen

New Orleans Garden Society

New Orleans Horticultural Society

Louisiana Pecan Growers Association 

7 HIS descriptive plant list is for the use of the resident agents of Jungle Gardens, Inc., and is not for general dis1 tribution to the public.

As Jungle Gardens, Inc., does no retail business from the home nursery it will positively not accept orders for local shipment. Agents are requested, therefore, to send no orders to the nursery for less than a carload.

Jungle Gardens, Inc., has developed a system of growing and marketing its plants with a minimum expense.

It offers to the public a quality of plants not surpassed by any nursery, and at prices that defy competition, but, these low prices are only obtainable through our several agencies, and for plants to be delivered by our agents.

Due to the extremely low price of our plants, all purchasers must distinctly understand that we will not replace a plant should one die.

We take pride in guaranteeing our plants true to name, free from disease, and in good, healthy growing condition. Our experience is that less than one-half of one per cent of our plants die after being set out.

We urge upon our agents and the public to get their plants set out as soon as possible after November I 5 th, as the spring growth then will be rapid and strong due to the new root system which will be developed during the winter, while the top of the plant is dormant.

We will be glad at all times to give prospective customers expert advice in all matters pertaining to the care of plants and landscaping.

We have in our employ a number of expert horticulturists and landscape engineers, and will be glad to send one of them for conference with customers, on a guarantee payment of his expenses and a per diem of $\$ 15.00$.

One of our specialties is the planning and laying out of golf courses, city parks and school grounds, in all of which we have had great experience. 
JUNGLE GARDENS, INC.

E. A. McIlhenny, Pres.

Avery Island, Louisiana

Members of

American Association of Nurserymen

Southwestern Association of Nurserymen

New Orleans Garden Society

New Orleans Horticultural Society

Louisiana Pecan Growers Association 


\section{Deciduous Trees and Shrubs}

The line of distinction is of ten narrow, but a shrub has usually a number of stems branching from the ground, while a tree has a single trunk or stem.

Very few of the evergreens are as free bloomers, and as rich in color, as are deciduous shrubs. They are naturally bare in winter, but the fresh spring foliage often accompanied by the flowers add life to the landscape effect, in late winter and early spring, that would otherwise be dull and uninviting to the eve.

Deciduous shrubs should only be pruned immediately after flowering; to prune in winter means the losing of many of the flowers.

Among the deciduous plants may be found many that make excellent specimens for the lawn or for street planting. The small ones are valuable in borders for their wealth of flowers and rich foliage.

No garden can be complete without a few of these very desirable subjects. Acacia Farnesiana (Sweet Acacia) Mexico.

A fast-growing, deciduous shrub or small tree, reaching $\mathrm{I} 2$ to $\mathrm{I} ; \mathrm{ft}$. in height with mimosa-like foliage, producing small, deep yellow, globular flowers. Grown in France for perfumery. The large, pea-shaped seed pods contain tannin. Used to advantage as background to shrubbery. Should be grown in full sun.

$$
\text { Bare root__ } 3-4 \mathrm{ft} . \quad \$ \mathrm{I} .25 \text { each }
$$

Albizzia julibrissin (Mimosa) Persia.

A large, flat-topped tree reaching 25 to $30 \mathrm{ft}$. in height, with a corresponding spread. Foliage large, mimosa-like. The tree literally covered in May and June with fluffy-like flowers, 2 to $2 \frac{1}{2}$ inches across, ranging in color from pinkish white to dark pink; very effective when in bloom. Useful for background planting, and as individual specimens where space permits. Should be grown in full sun.

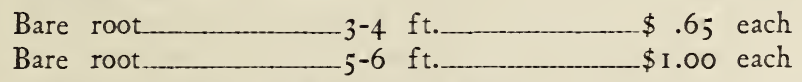

\section{Aleurites Fordii (Tung-oil Tree) China.}

A very ornamental shade tree, reaching $25 \mathrm{ft}$. in height. Has a smooth, dark green bark, and large, effective, heart-shaped foliage. Flowers reddish white in large panicles opening in the spring, followed in September with walnut-like, poisonous nuts, which furnish a commercial oil used in the manufacture of paints and varnishes. Should be grown as individual specimens, especially adapted as lawn trees for shade.

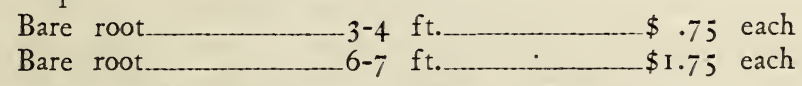

Aralia pentaphylla (Rice-paper Plant) Japan.

A graceful shrub reaching $10 \mathrm{ft}$. in height, with arching branches, and bright green, shiny foliage. It has a few small thorns at base of leaves. Useful for shrubbery and background planting.

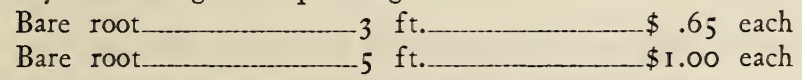

Aralia spinosa (Devil's Walkingstick) Southern States.

Upright in growth, branching close to the ground, reaching $2 ; \mathrm{ft}$. or more in height. Stems very thorny. Its large cut leaf foliage and small, whit- 
ish flowers in heavy terminal panicles, gire the shrub a fine, sub-tropical appearance. Fine for shrubbery and background planting.

$$
\text { Bare root }
$$

\section{Catalpa speciosa (Western Catalpa) Southern States.}

A large, ornamental shade tree, with bold, heart-shaped foliage. Flowers 2 inches across, white, spotted brown inside, produced in large panicles. Makes a desirable street tree; also useful for background planting and individual specimens.

Bare root 6-8 ft. $\$ 1.50$ each

\section{Cydonia japonica (Japanese Flowering Quince) Japan.}

Low-growing, branching shrub up to $6 \mathrm{ft}$. in height, with spiny branches covered in early spring with bright scarlet flowers before the young leaves appear. Very effective in massed plantings where striking effects of color are desired in February and March. Useful for foreground planting and will stand partial shade.

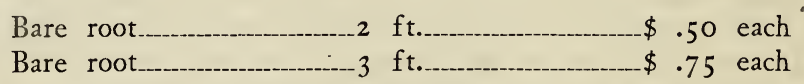

Cercis canadensis (Redbud, Judas Tree) Southern States.

A loose-growing tree reaching 25 to $30 \mathrm{ft}$. in height. It has dark brown wood and handsome, distinct, heart-shaped foliage. The branches are covered in early spring, before foliage appears, with bright red flowers. Very effective and ornamental. Useful for shrubbery planting in sun or partial shade.

$$
\begin{aligned}
& \text { Bare root__-_ } \$ \text { ft. } .75 \text { each }
\end{aligned}
$$

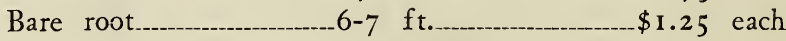

\section{Cornus florida (Flowering Dogwood) Southern States.}

Small tree with spreading branches reaching 30 or more feet in favorable situations. Grows equally well under large trees in shade, or in full sun. It has handsome foliage with a brilliant fall coloring, and is literally covered in early spring, before the foliage appears, with white blossoms 2 to 3 inches across. One of the most beautiful native trees.

Balled
Balled
$-12-3 \mathrm{ft}$

\section{Deutzia scabra (Pride of Rochester) Japan.}

Small, low-growing, bushy flowering shrub reaching $6 \mathrm{ft}$. in height. Small, dull green foliage, and is covered with white blossoms in early spring, giving the effect of a bank of snow. Useful for foreground planting of shrubbery and excellent for mass effects. Does well in partial shade and Northern exposures.

Balled
Balled
2-3

Diospyros virginiana (Persimmon) Southern States.

A slow-growing, upright tree reaching $30 \mathrm{ft}$. or more, fruit attractive, persisting until frost.

Bare root $4 \mathrm{ft}$. $\$ 1.25$ each 


\section{Diospyros kaki (Japanese Persimmon) Japan.}

A low-spreading tree of attractive growth, bearing a great abundance of large, highly colored, delicious fruit, some varieties weighing a half pound each.

$$
\begin{aligned}
& \text { Bare root } \\
& \text { Bare root } 6 \mathrm{ft} \\
& \mathrm{ft}
\end{aligned}
$$

Forsythia viridissima (Golden Bells) China.

Shrub with green, erect branches reaching $10 \mathrm{ft}$. in height, covered in early spring with bright, golden yellow flowers in great profusion, the entire length of the branches. One of our showiest early flowering shrubs, well adapted for use in shrubbery and for mass effects.

$$
\begin{aligned}
& \text { Balled _ 2-3 ft.__ \$ \$ \$ } \\
& \text { Balled __ - \$1.25 each }
\end{aligned}
$$

Hibiscus moscheutos (Giant Rose-Mallow) Eastern States.

Strong growing perennial 7 to $8 \mathrm{ft}$. in height, having heavy roots throwing up strong shoots in early summer and covered until winter with showy blossoms 4-6 inches across, ranging in color from white to dark maroon. This variety is the finest and showiest of all the marsh-mallows and one of our boldest subjects for planting in borders and roomy places, particularly in damp soil.

$$
\text { Balled__ } 2 \text { yr. old roots_\$ \$ } 50 \text { each }
$$

Hibiscus syriacus (Althea, Rose of Sharon) Asia.

Tree-like shrub with many upright branches reaching $12 \mathrm{ft}$. in height. Flowers borne in great profusion throughout entire summer resembling small double Hollyhocks $2 \frac{1}{2}-3$ inches across. Excellent for use in shrubbery or for avenue effects, where larger trees are not permissible. Color, double light pink.

$$
\begin{aligned}
& \text { Balled } \quad 3 \mathrm{ft} . \\
& \text { Balled } \\
& \mathrm{ft}
\end{aligned}
$$

Hydrangea otaksa (French Hybrids) Garden origin.

Ornamental, much-branched, woody shrub, reaching large proportions if allowed to grow unpruned. Large, bright, glossy, green leaves. Flowers borne in large trusses, opening in May and remaining on the shrub for many months. Colors range from white through the pinks to a deep cobalt blue. An excellent subject for foundation planting, on East and Northern exposures. Equally at home under trees where shade is not too dense.

Balled
Balled

Hypericum Moserianum (St. Johns Wort) Garden Hybrid.

Subshrub up to $4 \mathrm{ft}$. in height with ends of branches pendulous, small, glossy foliage almost evergreen, flowers 2 to 3 inches across, deep yellow, with spreading petals and numerous long stamens tipped with red. Blooms continuously and prefers partial shade. Excellent subject for foundation planting.
Balled
$\mathrm{I} \frac{1}{2}-2 \mathrm{ft}$
$\$ .75$ each
Balled
$2-2 \frac{1}{2} \mathrm{ft}$
$\$$ I.00 each

\section{Koelreuteria paniculata (Golden Rain Tree) Korea.}

Tree to $30 \mathrm{ft}$. in height; leaves large, I 2 to I 4 inches long, with 10 or more leaflets; flowers yellow, borne at ends of branches in broad panicles 12 to 
I 8 inches long, followed by conspicuous red, bladder-like seed pods. Excellent as an individual specimen for lawn, background planting or street tree.

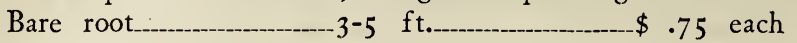

\section{Lagerstroemia indica (Crepe Myrtle) India and China.}

One of our noblest flowering small trees with smooth, brownish bark and small, glossy, green leaves; flowers produced at tips of branches in large trusses opening early in June, ranging in color from white to purple. Should be grown in every garden and excellent for street planting. If pruned slightly after first flowering, will give a wealth of bloom again in the Fall. Colors, Watermelon Red, Pink, Lavender and White.

Balled
Balled
-

Liriodendron tulipifera (Tulip Tree) U. S.

A strong growing forest tree belonging to the Magnolia family. Leaves large and attractive. Flowers resemble closely the garden tulip and about the same size; yellow-green, conspicuously marked with orange, the fruit, an upright cone, decorating the tree all winter. A splendid shade tree, and one of the best for street planting.

$$
\text { Bare root__- } \$ \mathrm{ft} \text {-00 each }
$$

Parkinsonia aculeata (Jerusalem Thorn) Trop. America.

Sub-tropical tree $\mathbf{I} 2$ to $\mathbf{I} 5 \mathrm{ft}$. tall and spreading with light green, smooth bark and spiny thorns I to $\mathbf{I} \frac{1}{2}$ inches long; foliage large and feathery-like, covered in summer with small, fragrant flowers. Fine as individual specimen and street tree; also makes an effective tall hedge.

Bare root
Bare root $\quad-\$ \mathrm{ft}$
$6 \mathrm{ft}$

Philadelphus coronarius. (Syringa) (Mock Orange) Armenia.

Woody shrub to Io $\mathrm{ft}$.; leaves oval-lanceolate, $\mathbf{I} \frac{1}{2}$ to 4 inches long by $\mathrm{I}$ to 2 inches broad, slightly hairy beneath. Flowers in rather dense racemes, white with slight creamy tone, very fragrant; blooms in May and June. No garden should be without this shrub.

$$
\text { Bare root_- } 1 \frac{1}{2}-2 \mathrm{ft} \text {. } \$ \text {. }
$$

Photinia villosa. China.

Upright shrub to I $5 \mathrm{ft}$. Leaves sharply serrated, dark green, glabrous above. Flowers $\mathbf{I}_{2} \frac{1}{2}$ inches broad, white in early spring. Fruit $\frac{1}{3}$ inch long, bright scarlet, holding until late winter. Very showy.
Bare root. $4 \mathrm{ft}$.
$\$ .75$ each
Bare root
$6 \mathrm{ft}$.
$\$ 1.50$ each

Populus alba nivea (Silver Poplar) U. S.

Large, much-branched, rapid-growing tree, with large leaves, glossy green above and white beneath. Useful for foliage effects in large plantings.
Bare root 6-8 $\mathrm{ft}$. $\$ 1.00$ each

Populus deltoides (Carolina Poplar) U.S.

Large, rapid-growing tree, somewhat spreading in habit, with large, bright green, glossy leaves, broader than long. Splendid street tree. Excellent as individual specimen and for foliage effects in large plantings.

Bare root___ $6-8 \mathrm{ft}$. $\$ \mathbf{1} .00$ each 


\section{Populus nigra italica (Lombardy Poplar) Italy.}

A very fast growing tree, having tall, narrow, columnar growth. Widely known for its individuality. Of value where strong contrast in planting is desired.

Bare root $\quad 4-5 \mathrm{ft}$
Bare root $\quad \$ 50$ each

Punica legrelli (Flowering Pomegranate) Garden origin.

The well-known, double-flowering, scarlet pomegranate, a large, muchbranched shrub I 2 to I $5 \mathrm{ft}$. high. Bright, glossy, green foliage with ruddy tints on new growth and showy, scarlet, double flowers 2 inches and more across. Excellent for interspersing in shrubbery and as individual specimens, also adapted for large hedges.

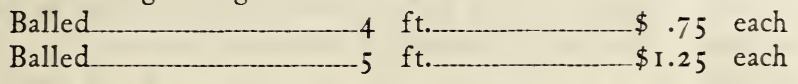

Salix elegantissima (Weeping Willow) Garden origin.

The well-known weeping willow. Very effective when properly placed in water effects and for cemetery use. Reaches large proportions up to $30 \mathrm{ft}$. in height, with equal spread in rich soil where plenty of moisture is available.

Bare root
Bare root

Sambucus canadensis laciniata (Cutleaf Elder).

Small spreading shrub to $4 \mathrm{ft}$. in height with large, much-dissected foliage. Most effective when corered in summer with enormous panicles of white flowers followed with bunches of small, blue-black berries. Useful for shrubbery planting.

$$
\text { Bare root___ } 4 \mathrm{ft} \text {. } \$ \text { I.00 each }
$$

Sapium sebiferum (Chinese Tallow Tree) China.

Tall tree to $30 \mathrm{ft}$. in height, with broad, effective foliage beautifully colored in fall. Flowers whitish in terminal racemes followed by interesting, small fruits, of which the chickens are very fond. The wax of the seed covering has an economic value in the making of candles, soap, etc. Useful for individual specimens and in large plantings. Should be in every barn yard.
Bare root $4 \mathrm{ft}$.
Bare root
$\mathrm{ft}$.
$\$ .75$ each
$\$ 2.00$ each

Sesbania tripetii. Argentina.

Small tree to $6 \mathrm{ft}$. Leares mimosa-like, flowers orange red in drooping racemes. A very showy shrub when a number are planted close together, as the bloom is profuse and very showy, and if pruned back after the spring bloom will make a second and third bloom during the summer. Should be heavily winter pruned as the bloom is made on the young growth.
Bare root $2-4 \mathrm{ft}$.
$\$$ I.OO each
Bare root
4-6 ft.
$\$ 1.50$ each

Spiraea bumalda "Anthony Waterer" (Crimson).

Small compact shrub 2 to $3 \mathrm{ft}$. high, very free flowering, bright crimson, rather dense clusters. Excellent for foreground plantings. Prefers an Eastern or Northern exposure. Will stand partial shade.

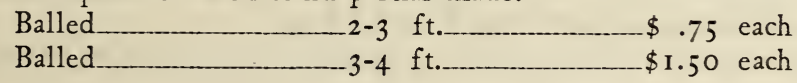




\section{Spiraea Billiardi. Garden origin.}

Rather upright-growing, reaching $5 \mathrm{ft}$. in height. Flowers produced in spike-like trusses at ends of shoots 6 to 8 inches long, bright pink in color and very effective for foreground planting. Prefers Eastern and Northern exposures. Will stand some shade.

Balled
Balled

Spiraea prunifolia fl. pl. (Double Bridal Wreath) China.

Graceful, much-branched shrub reaching $8 \mathrm{ft}$. in height. One of the most effective of all the spiraeas. Its long, arching branches covered with snowwhite, double flowers the entire length, produced in very early spring, make it one of the most popular of our early flowering shrubs. Can be used as individual specimens or in the foreground of shrubbery planting.

Balled
Balled.

Spiraea Thunbergi. Japan.

Much-branched shrub to $5 \mathrm{ft}$. in height. A very graceful, early-flowering shrub with feathery, light green foliage, its slender arching branches covered with single white blossoms. Useful for low plantings in mass effects and foundation shrubbery.

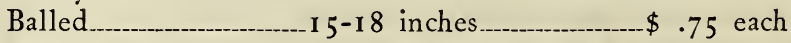

\section{Spiraea Van Houttei (Bridal Wreath) Garden Origin.}

Shrub 6-8 $\mathrm{ft}$. high with arching branches and drooping with a wealth of snowy white single blossoms, the whole bush resembling a bank of snow, when in full bloom. Excellent for individual specimens, foundation planting and for banking in shrubbery.

Balled
Balled

Sterculia platanifolia (Varnish Tree) China.

Strong-growing, smooth-barked, round-headed tree of medium size. Leaves very large, five-lobed, like maple leaves, flowers small, greenish white. A splendid shade tree for lawn or street border.

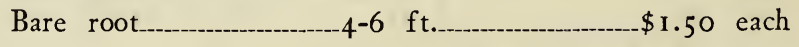

Symphoricarpos albus (Snowberry) Northern U. S.

Shrub with slender upright branches 2 to $5 \mathrm{ft}$. high, leaves small and airy, giving the impression of maiden hair fern. Flowers pinkish in terminal spikes, fruit globose, snow white $\frac{1}{4}$ to $\frac{1}{2} \mathrm{ft}$. long, holding until late winter.

$$
\text { Balled _- } 3-4 \mathrm{ft} \text {. } \$ 1.00 \text { each }
$$

\section{Tamarix gallica (Salt Cedar) W. Europe.}

Shrub or small tree 8-12 ft. with slender spreading branches, clothed with fine feathery foliage. Flowers borne in large trusses, pink in color. In summer very decorative. Fine for seaside planting and low, wet soils.

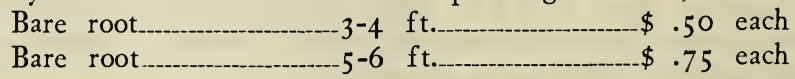

Ulmus americana (American Elm) U.S.

Ornamental tree attaining large proportions and one of our favorite sub- 
through. One of our best shrubs for foundation planting and massed effects; does well in sandy soil and prefers full sun.

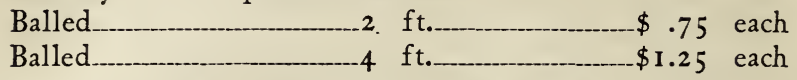

Ardisia crenulata (Christmas Berry Bush) E. Indies.

A handsome shrub 3 to $5 \mathrm{ft}$. in height, grown for its beautiful foliage and drooping clusters of coral-red, attractive berries, which hang on the plant the whole winter through. Leaves are bright and shiny, with wavy margins 8 to 12 inches long and 2 to $2 \frac{1}{2}$ inches across. Flowers white in terminal panicles; fragrant. Its very decorative fruit makes it one of the choicest ornamentals for the winter months. Excellent for grouping and for foundation planting.

$\begin{array}{ll}\text { Balled } & \text { \$I.00 each } \\ \text { Balled } & 2 \mathrm{ft}\end{array}$

Azalea indica formosa. China.

Well-known, compact, slow-growing shrub covered in late winter with large, funnel-shaped flowers, rosy and carmine in color. Grows equally well in any situation, making it, without doubt, the most popular flowering plant grown in the South today. Commercial fertilizers should never be applied to Azaleas; use only nature's plant food which is sold under the name of humus.

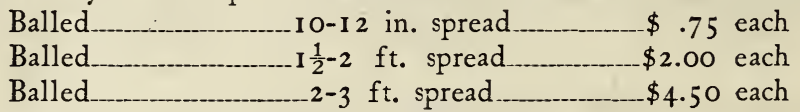

Buddleia asiatica. Eastern Asia.

Fast-growing shrub or small tree Io to I $5 \mathrm{ft}$. in height, large foliage, leaves 4 to 8 in. long, light green above, whitish beneath. Flowers bloom in mid-winter and they are white, fragrant, in slender drooping panicles 3 to 6 inches long. Should be grown in sunny, sheltered situation. Excellent as background planting in shrubbery.
Balled
$3-5 \mathrm{ft}$
$\$ 1.50$ each

Buddleia officinalis. China.

Another mid-winter flowering variety similar to asiatica, but with lilac colored flowers.

Balled____ 3-5 ft._____ \$I each

\section{Buddleia magnifica. China.}

A very handsome species with showy flowers appearing in great profusion through the summer months. Flowers in dense terminal panicles 6-8 inches long, deep rose purple in color. Prune severely in late winter before growth commences to encourage bushy habit.

$$
\text { Balled______ } \$ .75 \text { each }
$$

Buxus japonica (Common Creole Boxwood) Japan.

Ornamental shrub grown chiefly for its handsome foliage. Excellent for low-growing hedges, bordering walks, etc., and for trimmed specimens in vases and porch receptacles. Can be trimmed to any height or shape.

\begin{tabular}{l} 
Balled \\
Balled \\
\hline
\end{tabular}

Camellia japonica. Sub-tropical Asia.

Well known shrubby tree, reaching 20 to $25 \mathrm{ft}$. in height with large, dark, glossy leaves, covered in winter with flowers 3 to 6 inches across, ranging in color from waxy white through the pinks and reds. Grows very slowly but 
begins blooming when young. Should be in every garden, as they are so extremely beautiful when in flower that all the care given them is well repaid.

Balled__ $\quad \$ 2.00$ each
Balled $\quad 2-3 \mathrm{ft}$ - $\$ 3.50$ each

Cassia corymbosa (Flowering Senna) Argentina.

Very free-flowering shrub 6 to $\mathrm{I} 0 \mathrm{ft}$. in height, large, mimosa-like foliage. Flowers yellow in long stalked trusses opening in early summer. Excellent for dry situations, on banks or mixed with shrubbery.

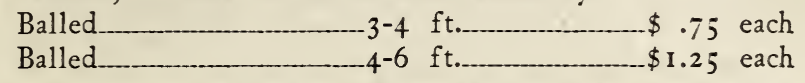

Cestrum nocturnum (Queen of the Night) W. Indies.

Loose-growing shrub with slender branches rising from the ground 6 to $8 \mathrm{ft}$. in height, foliage attractive and light green. Flowers continuously through summer months, greenish white in color and very fragrant at night. Rather tender but growing readily from the ground each year. Excellent for shrubbery planting on account of its very fragrant flowers.

$$
\text { Balled__Strong plants_\$2.00 each }
$$

Cinnamomum camphora (Camphor Tree) China.

One of our best evergreen shade and street trees, reaching 25 to $30 \mathrm{ft}$. in height. Foliage very attractive and strongly scented with camphor. Bright, glossy green and having a reddish tint when young. Commercial camphor is extracted from the wood:
Balled $-3 \mathrm{ft}$ $\$ .75$ each
Balled $5 \mathrm{ft}$. $\$ 1.50$ each

Cocculus laurifolia. Himalayas.

A very handsome shrub of recent introduction, with ornamental foliage, io to $\mathrm{I}_{5} \mathrm{ft}$. in height, with arching branches. Leaves 4 to 6 inches long, bright green and glossy; strongly veined. Excellent for foreground and foundation planting, giving a very pleasing foliage effect.

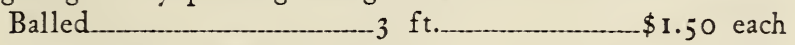

Elaeagnus pungens reflexa. Japan.

An ornamental shrub with interesting foliage, leaves 2-4 inches long, light green above, silvery beneath, and covered with brown scales. Flowers are inconspicuous, followed by fruit about $\frac{3}{4}$ inches long and mottled like the foliage. Should be pruned while growing if desired to grow in shrub form, but excellent for covering old stumps or unsightly objects, as its long branches will grow Io $\mathrm{ft}$. or more in one season.

Balled__ $3 \mathrm{ft}$
Balled
ft.

Eriobotrya japonica (Loquat) Japan.

Small tree to $20 \mathrm{ft}$. in height. Very striking foliage 6 to 10 inches long, bright green above, rusty beneath. Flowers white, almost hidden in their rusty, woolly covering; very fragrant; borne throughout the winter months, followed with yellow fruit $\mathbf{I} \frac{1}{2}-2$ inches long and pear-shaped, of an agreeable acid flavor. Used for background planting and as individual specimens, plant where the fragrance of the blossoms may be enjoyed during the winter months.

Balled
Balled__ $3 \mathrm{ft} . \$ 2.00$ each
$-11-\$ 5.00$




\section{Erythrina crista-galli (Coral Tree) Brazil.}

A bushy-like tree usually with a very short trunk, throwing up strong branches from the stem near the ground each year. Flowers striking, large and brilliant crimson in color, borne in dense panicles in early summer. Does best when pruned back to the old wood before growth commences.

$$
\text { Balled._- } 3-4 \text { ft._._- }
$$

Erythrina herbacea. Southern States.

Native perennial, with several stems growing from the ground in early spring, 2-4 ft. high. Flowers 2 inches long, deep scarlet, in loose spikes 2 to 3 ft. high. Useful for foreground planting in borders.
Balled
Large clumps.
$\$$ I.50 each

Escallonia Berteriana. South America.

An interesting shrub 5 to $6 \mathrm{ft}$. in height, with dark green, glossy foliage. Flowers are pure white resembling somewhat the old-fashioned lilac of gardens. Useful for shrubbery and foundation planting.

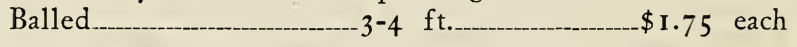

\section{Fatsia papyrifera (Chinese Paper Plant) Formosa.}

A striking plant, large, palmate foliage, with tropical effect, reaches 15 to $20 \mathrm{ft}$. in height. Flowers rather inconspicuous in large clusters. Useful for planting in shady places where tropical effect is desired, and excellent for waterside planting.

$$
\begin{aligned}
& \text { Balled } \\
& \text { Balled }
\end{aligned}
$$

\section{Gardenia florida (Cape Jasmine) China.}

Small, dense-growing shrub 3 to $5 \mathrm{ft}$. in height, with very glossy, attractive foliage and large, double, waxy Camellia-like fragrant flowers, borne in May and June. Excellent for foundation and foreground planting, also useful for hedges $2 \frac{1}{2}$ to $3 \mathrm{ft}$. in height.

Balled
Balled
Balled

Gardenia radicans.

A smaller growing variety of Gardenia florida, making attractive dense bushes 2 to $3 \mathrm{ft}$. high, and bearing small, white flowers $\mathbf{I} \frac{1}{2}$ to 2 inches across. Should be grown in a warm, sunny situation.

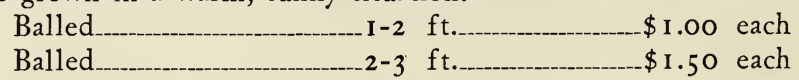

Ilex opaca (American Holly) U. S. A.

An ornamental, slow-growing tree, with spreading, short branches, 20 to 30 ft. in height; fine, dull green, glossy foliage; leaves, 2 to 4 inches long. Covered in winter with dull scarlet holly berries. Useful for background planting and small avenue effects.

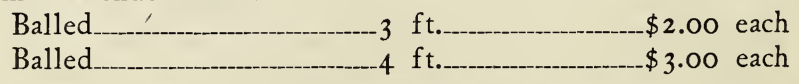

\section{Ilex vomitora (Native Yaupon) Southern States.}

A shrubby tree with spreading branches, small foliage, leaves $\frac{1}{2}$ to I inch long, literally covered all winter with small, bright'orange holly berries. One of our best subjects for a $2 \frac{1}{2}$ to $4 \mathrm{ft}$. hedge; for permanency cannot be equalled 
in the South. Useful also for background planting when allowed to grow naturally.

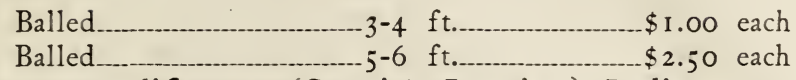

Jasminum grandiflorum (Spanish Jasmine) India.

A loose-growing, nearly erect shrub, prized for its attractive, white, fragrant flowers, reaching 7 to $8 \mathrm{ft}$. in height. Excellent for shrubbery planting.
Balled. 2-3 ft.
$\$ 1.50$ each

\section{Jasminum nudiflorum. China.} flowers.

Similar to the above but not such a vigorous grower, and having rellow

$$
\text { Balled ___ 2-3 ft.____ \$ } \$ .50 \text { each }
$$

Jasminum white star.

A smaller growing variety, with almost ever-blooming white flowers. Excellent for covering banks and foundation planting.

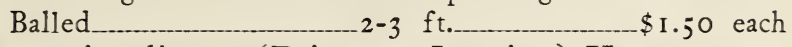

Jasminum primulinum (Primrose Jasmine) Yunnan.

The strongest growing of all the Jasmines, making a very large bush when allowed to grow naturally, doing best if supported. Bright green, attractive foliage, blooms in mid-winter with numerous large, yellow blossoms.
Balled
Balled
$-3 \mathrm{ft}$.
$5 \mathrm{ft}$.
$\$ .75$ each
$\$ 1.25$ each

\section{Ligustrum gracilis (Bushy Waxleaf Privet) Japan.}

Our most popular shrub for foundation planting, under almost any condition; also makes an excellent large hedge. Heary, black-green, glossy foliage leaves, 2 to 3 inches long. Corered in early spring with fragrant white blossoms resembling the old-fashioned lilac, followed by bunches of small, blueblack berries. Indispensable where a shrub of 4 to $8 \mathrm{ft}$. in height is required. Should be pruned in summer after flowering.

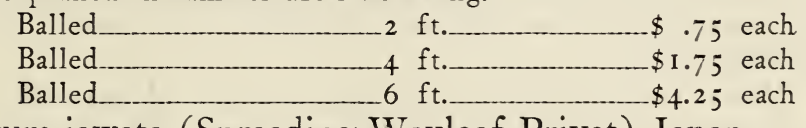

Ligustrum iawata (Spreading Waxleaf Privet) Japan.

Similar to gracilis but having smaller foliage, with slight yellow variegation and much more spreading in habit.
Balled $3 \mathrm{ft}$
$\$ 1.25$ each
Balled
$4 \mathrm{ft}$. $\$ 2.50$ each

Ligustrum lucidum (Glossy Tree Privet) China.

A tree form of Privet used extensively for street and arenue planting; also makes a very desirable shade tree. Foliage of lighter green than gracilis and more tree-like, reaching 20 to $25 \mathrm{ft}$. in height.
Balled
Balled
$4 \mathrm{ft}$.
$7 \mathrm{ft}$.
$\$ .75$ each
$\$ 2.50$ each

Magnolia grandiflora. Southern States.

A noble native tree attaining a height of 50 to $75 \mathrm{ft}$; recognized as one of the grandest of all broad-leafed, evergreen trees. Leaves thick and bright, glossy above and lighter beneath, 5 to 8 inches long. Flowers white, fragrant, sometimes 12 inches across. Opening in May.

$\begin{array}{ll}\text { Balled } & 2 \mathrm{ft} \\ \text { Balled } & 4 \mathrm{ft} \\ -13- & \$ 1.25 \text { each }\end{array}$


Mahonia aquifolium (Oregon Grape).

Small, bushy shrub, 3 to $6 \mathrm{ft}$. in height, very attractive foliage, 8 to 12 inches long, with holly-like leaflets. Flowers in late winter in large terminal trusses, bright yellow in color, followed by bunches of grape-like berries, blueblack in color. Very useful for mass effects, and for foundation and foreground planting. Does well in partial shade.

Balled_- $\$ 1.50$ each
Balled-\$2.00 each

Malvaviscus grandiflora (Giant Turk's Cap) S. America.

Tall shrub with slender stems, leaves light green and heart-shaped. Flowers, borne in profusion almost continuously, bright scarlet, shaped like a Turk's cap, 3 inches long. Excellent for shrubbery planting and in sheltered situations, somewhat tender but growing from the ground again in the spring. Best pruned to the ground every year in late winter.
Balled 2 yr. old plants $\$ 1.25$ each
Balled 3 yr. old plants. $\$ 2.50$ each

Myrtus communis microphylla (True Classic Myrtle) S. Europe.

A very attractive, small shrub, reaching $6 \mathrm{ft}$. or more in height, with small, dark green, glossy foliage, having a very aromatic odor, small, white, fluffy flowers borne in summer, followed by small black berries $\frac{1}{2}$ inch in length. Excellent for foundation and foreground planting and low hedges. Can be pruned to any desired shape.
Balled
I-2 ft.
$\$ 1.50$ each
Balled $3 \mathrm{ft}$. $\$ 3.00$ each

Nandina domestica. Japan.

One of the sacred plants of Japan. A small, slender shrub with bamboolike stems 3 to $5 \mathrm{ft}$. in height, covered with fern-like foliage. Flowers pinkish white in terminal clusters, followed by brilliant scarlet berries, which hang on all winter. One of our most attractive shrubs, unexcelled for foundation and foreground planting, and very effective when planted in masses. Should be in every garden.
Balled
$2 \mathrm{ft}$.
$\$ 1.50$ each
Balled
$3 \mathrm{ft}$.
$\$ 2.00$ each

\section{Nerium oleander (Oleander) S. Europe.}

The old-fashioned evergreen shrub grown everywhere in the South. Erect shrub reaching 10 to $12 \mathrm{ft}$. in height, foliage long and narrow and always attractive. Flowers borne in loose trusses. Colors: Cream, double pink, single pink, red and white.
Balled $2 \mathrm{ft}$. $\$ 1.00$ each
Balled $4 \mathrm{ft}$. $\$ 2.50$ each

\section{Persea glauca (Louisiana Sweet Bay) Southern States.}

Tree grown for its aromatic and culinary leaves, reaching $30 \mathrm{ft}$. or more in height. Leaves 3 to 5 inches long and $\mathbf{I} \frac{1}{2}$ to 2 inches wide, light green above, whitish beneath. Flowers inconspicuous, fruit $\frac{1}{2}$ inch long, black and pearshaped. This tree must not be confused with the swamp bay, which is Magnolia glauca, having small, white Magnolia blossoms. The leaves of this tree are used largely in seasoning the celebrated creole dishes of Louisiana. Should be in every Southern garden.

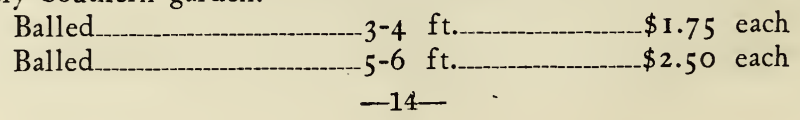




\section{Photinia serrulata. China.}

Large, round-topped shrub $\mathrm{I} 5$ to $20 \mathrm{ft}$. in height, very handsome foliage. Leaves 5 to 7 inches long and 2 to $2 \frac{1}{2}$ inches wide, dark green and glossy above, yellowish beneath. Flowers white in large heads, borne through the summer months. A very striking ornamental shrub. Excellent for background planting and individual specimens.

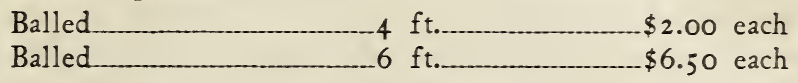

Pittosporum tobira. Japan.

Bushy shrub 6 to $8 \mathrm{ft}$. in height, leaves rich and glossy, 2 to $3 \frac{1}{2}$ inches long and $I$ to 2 inches wide. Flowers in late winter at tips of growth, white and fragrant, resembling orange blossoms. One of our most valuable shrubs for foundation and foreground planting. Excellent also for individual specimens; can be pruned during the growing season to any desired shape.

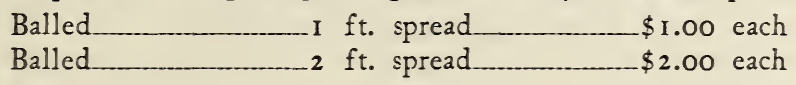

Pittosporum tobira variegata.

Growth like the ordinary Pittosporum but with silver gray leaves mottled with white. A very beautiful plant.

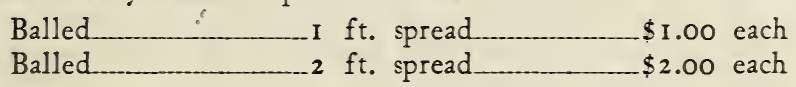

\section{Plumbago capensis. South Africa.}

A semi-climbing shrub making a rather dense, soft growth. Although somewhat tender, it readily sprouts from the root and makes a very attractive shrub in a few weeks. Blooms continuously, the whole plant covered with beautiful azure blue flowers. Useful for mass effects and foundation planting.

$$
\text { Balled_____ yr. old clump_____ \$1.00 each }
$$

\section{Podocarpus macrophylla (Japanese Yew) Japan.}

Ornamental tree grown principally for its attractive dense foliage 15 to $20 \mathrm{ft}$. in height, with horizontal spreading branches. Foliage very dark green, leaves 3 to 4 inches long and $\frac{1}{4}$ inch wide. Flowers inconspicuous. Very effective when pruned to an upright shape, making excellent specimens for lawn and foundation planting.

Balled
Balled
Balled

\section{Prunus caroliniana (Cherry Laurel) Southern States.}

A tree when allowed to grow naturally reaches 20 or more feet in height. Rich foliage, thick, dark green and shiny, 2 to $2 \frac{1}{2}$ inches long and $I$ to $1 \frac{1}{2}$ inches wide. Flowers white in narrow racemes 6 inches long. Should be pruned to any desired shape or size during the growing season. Excellent for large hedges, and one of our most valued shrubs for any situation in the garden.

Balled $3 \mathrm{ft}$. $\$ 1.25$ each

Balled $6 \mathrm{ft}$. $\$ 3.00$ each 
long and horn-like. The most popular of the Conifers for screening and large hedges.

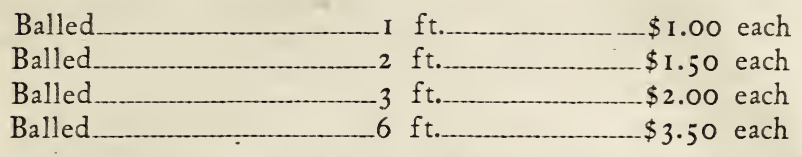

Thuya aurea conspicua (Goldspire Arborvitae) Garden Origin.

Very pyramidal in outline, attaining a height of $\mathrm{I} 2 \mathrm{ft}$. or more. The intense golden foliage suffused with green makes this variety very attractive during the winter months. One of the finest subjects for foundation planting and as individual specimens.

\begin{tabular}{|c|c|}
\hline-1 & $\$ 1.00$ \\
\hline Balled & $\$ 2.00$ \\
\hline Balled. & $\begin{array}{ll}\text { ft. } & \$ 3.00 \\
\text { ft. } & \$ 4.00\end{array}$ \\
\hline
\end{tabular}

Thuya aurea nana (Berkman's Golden) Garden Origin.

More conical in shape than the foregoing and dwarfer in habit; 5 to 7 ft. in height. The suffused golden coloring and very compact, fern-like foliage make this variety one of the most popular of the Thuyas.

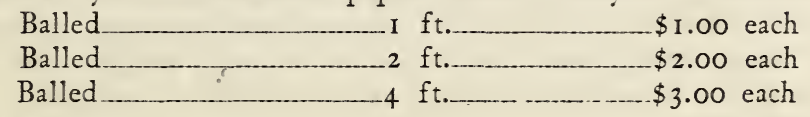

Thuya bonita.

Somewhat resembling Aurea nana in habit and growth, but a very distinct and pleasing green color. A fine individual specimen.

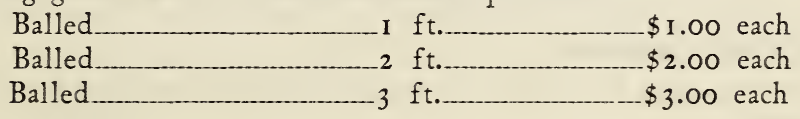

Thuya compacta.

Very compact pyramidal type, foliage green and fern-like, reaches 12 to $15 \mathrm{ft}$. in height and a very desirable form.

\begin{tabular}{lll} 
Balled & I ft. \\
Balled & \$ \\
Balled & ft. \\
\hline
\end{tabular}

Thuya globosa.

Globe-like in form, growing into a round ball, dark green with fine foliage 3 to $4 \mathrm{ft}$. in height. Excellent for individual specimens.

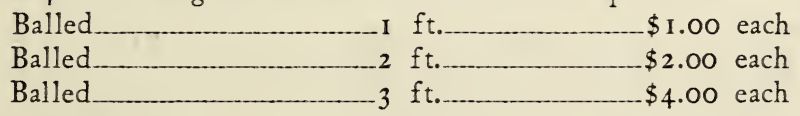

Thuya pyramidalis.

Tall and pyramidal in form, rather looser growing than compacta. Dark green and very imposing, fine for background when sky line is desired, and as an individual specimen. Reaches 15 to $20 \mathrm{ft}$. in height.

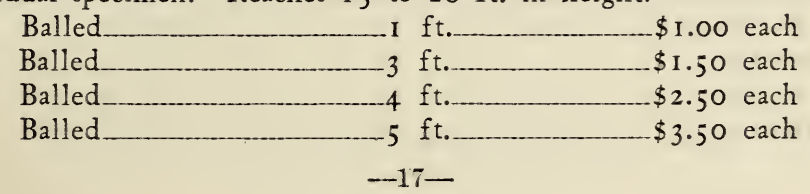




\section{Thuya Rosedale.}

A distinct type totally unlike the other Thuyas in appearance. Globular, merging into the conical in shape, reaching 4 to $5 \mathrm{ft}$. in height. Foliage very pleasing and distinct. Bluish grey in color and very fine and fern-like.

Balled_ron
Balled
Balled

\section{Cedrus deodara (Blue Cedar) Asia.}

Large, coniferous evergreen reaching 50 or more $\mathrm{ft}$. in height, with wide spreading branches becoming pendulous at the ends. Foliage needle-like, 2 to 4 inches long and usually grayish in color. An excellent specimen for the lawn where space permits, or for street planting.

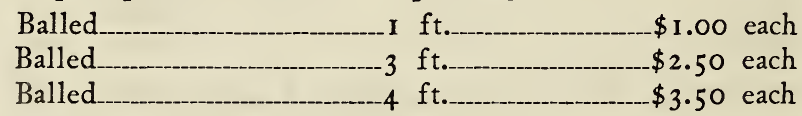

Chamaecyparis obtusa. Japan.

Slow-growing conifer, reaching large proportions in its native habitat. Has horizontal branches, the branches flattened and frond-like, pendulous at the tips. Foliage bright green and shiny above, with whitish lines beneath. Very desirable for foundation planting and as individual specimens.

Balled_roch
Balled
Balled

\section{Chamaecyparis pisifera.}

Similar to obtusa but smaller in growth and looser in habit and of a light green foliage.

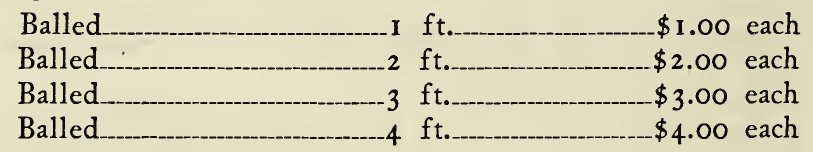

\section{Chamaecyparis plumosa.}

A variety of pisifera with foliage very plume-like and feathery, with a dense growth conical in outline. A very decorative Conifer with a pleasing green color.

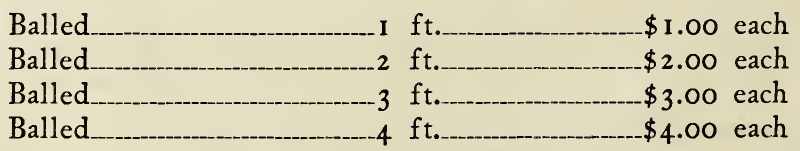

\section{Chamaecyparis plumosa aurea.}

An exceptionally fine variety of plumosa, with foliage of a golden hue.

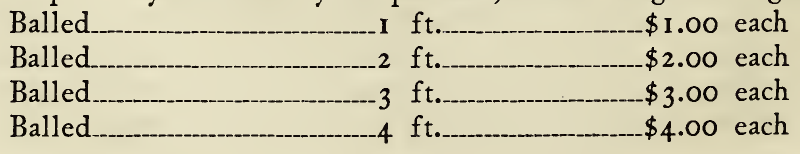


Chamaecyparis squarrosa Veitchi.

Another variety of pisifera with a densely branched habit, making it very distinct and pleasing. Branchlets are very feathery, bluish above and silvery beneath.

\begin{tabular}{|c|c|}
\hline I & $\ldots$ \\
\hline Bal & $\$ 2.00$ \\
\hline , & $\$ 3$ \\
\hline & \\
\hline
\end{tabular}

Cupressus sempervirens horizontalis (Horizontal Cypress) S.

Europe.

Tall-growing conifer, reaching 50 or more ft. in height, with horizontal branches and dark green foliage, having an aromatic odor.

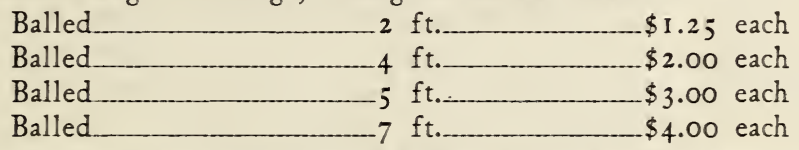

Cupressus sempervirens stricta (Italian Cypress) S. Europe.

A variety of the preceding, with stiff, short branches growing closely to the main stem, forming a narrow, columnar head, growing $20 \mathrm{ft}$. or more in height. This is the classical Cypress of the Greek and Roman writers.

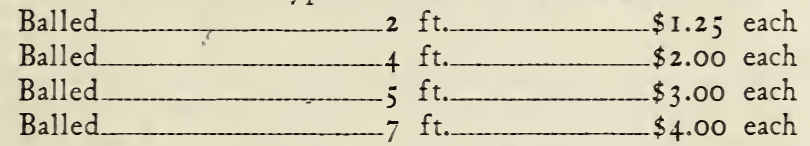

Juniperus chinensis (Chinese Juniper) China.

Loose-growing tree, reaching 20 or more $\mathrm{ft}$. in height, with rather slender branches. Leaves small and needly-like, of a grayish color. Useful as a specimen and for foundation planting.

\begin{tabular}{|c|c|}
\hline $\begin{array}{l}\text { Balled. } \\
\text { Balled. }\end{array}$ & $\begin{array}{l}\text { ft. } \\
\text { f }\end{array}$ ft. $\$ 2.00$ each \\
\hline Balled & $\$ 3.00$ each \\
\hline
\end{tabular}

Juniperus compacta depressa.

Compact-growing conifer with many branches clinging close to the ground; light green in color and with a spread of Io ft. or more erentually. Excellent for covering banks and for foreground planting.
Balled I ft. spread
$\$ 1.50$ each
Balled
$2 \mathrm{ft}$. spread
$\$ 2.50$ each

Juniperus Pfitzeriana.

Similar to the preceding in habit, but more vigorous in growth and very effective where a low-growing, spreading plant is desired.

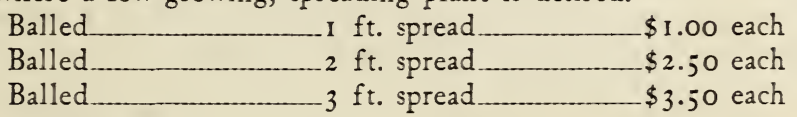

Juniperus sylvestris.

A variety of chinensis but smaller in growth and very dense and of a pleasing light green color. One of the best of the Junipers for specimens and foundation planting.

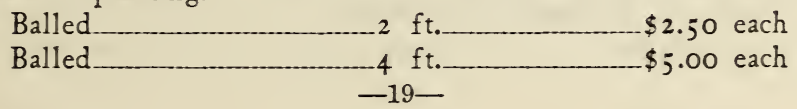




\section{Juniperus virginiana (Virginian Cedar).}

The well-known, so-called Cedar, with wood having an aromatic odor. Tall-growing and compact in habit, reaching 25 or more $\mathrm{ft}$. in height. The Southern type has feathery foliage, giving a pleasing contrast to the landscape. Splendid for large hedges as it prunes well.

Balled
Balled
Balled

Pinus caribaea (Slash Pine) Cuba.

A native Pine $100 \mathrm{ft}$. or more in height, with horizontally spreading branches forming a round-topped, broad and compact head. Leaves dark green and lustrous, pointed in whorls of threes and twos, 8 to 12 inches long.

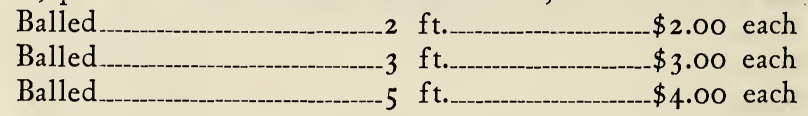

\section{Vines and Climbers}

Among the Vines and Climbers are to be found those subjects that are indispensable for covering bare walls, pergolas, fences, outhouses, etc. Bignonia ungus-cati (Yellow Trumpet Creeper) Argentine.

Woody evergreen tendril climber. Small, attractive foliage which clings closely. Flowers trumpet-shaped, 2 inches long, of a clear bright yellow, produced in early summer. A useful vine for covering buildings and outhouses.

$$
\text { I year plants. } \$ .75 \text { each }
$$

Ficus repens (Climbing Fig) Japan.

A close clinging evergreen vine with thick, leathery, dark green. foliage, small when young, $\frac{1}{2}$ inch long, becoming larger as the vine matures with leaves $I \frac{1}{2}$ to 2 inches long. Very slow in growth the first two years, afterwards growing very rapidly and covering large areas. Excellent for covering low walls where it can be controlled, and for large buildings where allowed to grow naturally. Prefers a sunny exposure.

$$
\text { Strong potted plants.__ } .75 \text { each }
$$

Hedera helix (English Ivy) S. Europe.

Well known root climbing vine with handsome evergreen foliage. Valuable for covering walls, trunks of trees and trellis work, also excellent for ground covering under trees and in the shade.
I year plants
$\$ .50$ each
2 year plants (heavy)
$\$ 1.50$ each

Lonicera americana (Common Honeysuckle) Southern States.

Medium growing shrubby vine, with evergreen foliage 2 to 4 inches long. Blooms continuously, flowers yellowish and very fragrant. Useful for covering old fences and unsightly banks.

$$
2 \text { year plants. } \$ .75 \text { each }
$$

Lonicera sempervirens superba (Red Flowering) Southern States.

A red flowering honeysuckle which blooms continuously. Very useful for covering fences and trunks of trees. Not so vigorous as common honeysuckle, but very valuable, as it blooms in mid-winter.

2 year plants $\$ 1.00$ each 
Trachelospermum jasminoides (Confederate Jasmin) China.

An evergreen, climbing, shrubby vine, with dark green, shiny leaves and covered in the Spring with small, white star, Jasmine-like, fragrant flowers. Should have a sunny exposure, and is equally effective when massed in beds and kept pruned low.

$$
\text { Strong plants___________ } \$ .75 \text { each }
$$

\section{Wisteria chinensis. China.}

Stout, deciduous vine, attaining woody trunk with age. The noblest of the woody vines when in blossom. The large trusses of blue, pea-shaped flowers in early spring are very attractive, and it is to be found growing in gardens all over the world.

$$
\text { I year old plants._._. \$ } .75 \text { each }
$$

Antigonon leptopus (Rosa de Montana) Mexico.

One of the most vigorous and beautiful flowering vines ever discovered. Foliage very profuse, large leaves, glossy and striking in appearance. Flowers of brilliant pink borne on long, graceful racemes, in bloom all summer. Killed to the ground in winter, but grows vigorously from the roots.

$$
\text { Balled__ Strong } 2 \mathrm{yr} \text {. old plants___ \$ } 50 \text { each }
$$

\section{Bamboos}

A very distinctive class of plants that are in reality giant ornamental grasses. We list here only a few varieties which have been found very hardy and best suited for local conditions. They make wonderful subjects as individual specimens on the lawn and are unexcelled as high screens to blot out undesirable objects. When used as screens or hedges they should be planted 5 to $6 \mathrm{ft}$. apart. The plants we offer are divisions from old clumps and have sufficient root strength to give immediate large effects. The first three varieties grow in the form of clumps and are most effective as screens or specimen plants. The last three increase from thick underground running roots, and are best used where a forest effect is wanted.

Bambusa Alphonse Karri (Golden Canes) Japan.

A variety having yellow stems reaching $1 ;$ to $20 \mathrm{ft}$. in height. Mature stems I to $I \frac{1}{2}$ inches in diameter, with fine green foliage.

$$
\text { Balled } 3 \mathrm{yr} \text { old clumps___. } \$ 5.00 \text { each }
$$

Bambusa argentea striata. Japan.

A variety having green stems, yellow striped, reaching 20 to $40 \mathrm{ft}$. in height. Mature stems I to $I \frac{1}{2}$ inches in diameter, with green foliage, which, when new, has a white stripe down the center of the leaf.

$$
\text { Balled _ } 3 \text { yr. old clumps_____ \$5.00 each }
$$

Bambusa nana (Curley Leaf Bamboo) Japan.

A smaller-growing variety reaching 10 to $\mathrm{I} ; \mathrm{ft}$. in height. Mature stems $\frac{3}{4}$ to $I$ inch in diameter with fine, green, curly foliage.

$$
\text { Balled____ } 3 \text { yr. old clumps_____\$ \$.00 each }
$$

Arundinaria Japonica (Japanese Cane) Japan.

Height 6 to $10 \mathrm{ft}$. Stems to $\frac{1}{2}$ inch thick. Leares large and showy, 6 to 10 inches long and I to 2 inches wide. A very hardy variety, splendid for background planting and where a thick, shut out hedge is wanted.

$$
\text { Balled }
$$
Single canes $\$ 1.00$ each 
Phyllostachys bambusoides (Giant Timber Bamboo) China.

Height to $85 \mathrm{ft}$. in rich bottom lands. Girth 16 inches. Stems dark green, very showy where forest effect is wanted. One of the hardiest; will stand $0^{\circ}$ and lower.
Balled
Single
$\$ 1.25$ each

Phyllostachys pubescens (Edible Bamboo) China.

Height 20 to $50 \mathrm{ft}$. Girth to 20 inches in rich bottom land. A wonderful plant for forest effect; the young shoots are delicious cooked as a vegetable and are a very favorite dish in China and Japan.

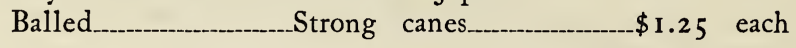

\section{Bulbs and Flowering Plants}

In this class are to be found those subjects that are rich in tropical effects and that consequently are at their best during the summer months. Planted around the pool and in secluded spots in the garden, they are very effective.

Alpinia nutans (Ginger Shell Flower) E. Indies.

Many-stemmed, leafy evergreen plant, with ginger-like roots reaching 8 to $10 \mathrm{ft}$. in height. Striking foliage, dark green leaves drooping in a spikelike raceme. Individual flowers resemble an orchid, yellow with pink suffusion, very sweet scented. Fine subject for foliage masses where tropical effect is desired, especially attractive when planted by water side.

Balled____ Strong clumps______ \$1.50 each

Aspidistra lurida. China.

A popular foliage plant, with large, stiff, shining leaves springing immediately from the ground. Leaves are practically stemless, I 8 to 24 inches long and 3 to 5 inches wide. Used extensively for indoor decoration and for planting in shady places where dark foliage effect is desired.
Balled or in pots. per leaf $\$ .15$ each

Colocasia antiquorum (Elephant Ear) India.

Herbaceous perennial arising from large rhizomes or tubers. Grown principally for their magnificent tropical foliage, which reaches large proportions under good culture, often 2 to $3 \mathrm{ft}$. long and $1 \frac{1}{2}$ to $2 \mathrm{ft}$. wide; shaped somewhat like an elephant's ear. Unsurpassed for foliage effects by water and for foreground planting in shrubbery where tropical aspect is desired.
Balled Large bulbs $\$ .75$ each

Colocasia odorata (Tree Elephant's Ear) E. Asia.

Similar to the above, but with larger leaves and longer stems. Balled. Large bulbs $\$ 1.50$ each

\section{Crinum finbriatulum (Milk and Wine Lily) Lower Guinea.}

Herbaceous, bulbous plant with a heavy stem with more or less elongated neck. Foliage light green, 2 to $2 \frac{1}{2} \mathrm{ft}$. long and 2 to 3 inches wide, arching and reaching to the ground. Flowers are borne on long stems well above the foliage, trumpet-shaped, 4 to 5 inches long in trusses, white with distinct red veins, fragrant. Fine for foreground plantings where tropical effect is desired, also good subject for the waterside.

Bare root__ Large bulbs_ $\quad \$ \quad 50$ each
Balled_o $\quad \$ 1.50$ each




\section{Hedychium coronarium (Common Ginger Lily) Asia.}

Many-stemmed, leafy, evergreen plant with ginger-like roots, closely resembling the Alpinia. Leaves are Canna-like green, smooth above, hairy beneath. Flowers are borne in a terminal spike, very showy, pure white and long-tubed, 2 to 3 inches across, very fragrant. Good subject where tropical effects are desired.

$$
\text { Balled__________._. } \$ 1.50 \text { each }
$$

Hemerocallis citrina (Gold Day Lily) China.

A fine leafed variety of this popular plant, flowers deep gold, resembling Easter lilies. Very fragrant.

$$
\text { Balled._._._. Strong plants_______ } .75 \text { each }
$$

Hemerocallis flava (Day Lily) Eastern Europe.

Popular, stout-rooted perennial, with abundant foliage, 18 to 24 inches long and $I$ to $I \frac{1}{2}$ inches wide, arching. Lemon yellow, lily-like flowers are borne on long stems. Blooms in early summer and is an excellent subject for mass and foreground planting.

$$
\text { Balled______._. } \$ .75 \text { each }
$$

Hemerocallis fulva. China.

An orange colored, flowering variety.

$$
\text { Balled__ Strong plants_\$ \$ } \$ .75 \text { each }
$$

Iris germanica (German Iris) Southern Europe.

Widely-known perennial with rhizomes or bulb-like root stocks. Narrow leaves 6 to $\mathrm{I} 2$ inches long with an erect habit. Flowers in terminal heads on long stalks 18 inches or more high. Colors vary from pure white to dark maroon, and are very effective for foreground planting.

Bare root__ 2 yr. old plants___ \$ .50 each

\section{Iris Kaempferi (Japanese Iris) Japan.}

More robust in habit than Germanica with leares I to $I \frac{1}{2} \mathrm{ft}$. long, with beautiful flowers $;$ to 8 inches across. Should be planted in rich, damp soil. An excellent subject for the water side.

$$
\text { Bare root__ } 2 \text { yr. old plants___ } \$ .75 \text { each }
$$

\section{Lantana camarra (Bush Lantana) Tropical America.}

Very floriferous under shrub, much branched with small foliage. Flowers continuously throughout the year in sheltered situations in dense, rather flattopped heads, $I \frac{1}{2}$ to 2 inches across, bright red in color. Excellent for color effects in masses and for foreground planting. Should be severely pruned when signs of new growth show in early spring.

$$
\text { Balled___._._. \$ . \$ each }
$$

Lantana Sellowiana (Trailing Lantana) S. America.

Very distinct in habit to Lantana camarra. Twiggy, slender plant, with trailing branches. Very showy with small, rosy, lilac colored flowers corering entire plant practically throughout the year. Very good subject for corering low fences 2 to $3 \mathrm{ft}$. in height.

$$
\text { Balled_Strong plant__ \$ \$ } 50 \text { each }
$$

Musa chinensis (Finger Banana) South China.

Tree-like herb, with perennial root stock. Fleshy stem 3 to $4 \mathrm{ft}$. high, with spreading leaves 2 to $3 \mathrm{ft}$. long and $\mathbf{I}$ to $\mathrm{I} \frac{1}{2} \mathrm{ft}$. wide. Increases in size 
by throwing up new shoots from the base. Fine subject for tropical effects in shrubbery and water side plantings.
Balled
Medium clumps
$\$ 2.00$ each

Musa oranocensis (Oranoco Banana).

A larger and more imposing variety than the preceding. Balled. Medium clumps. $\$ 2.00$ each

\section{Musa ensete (Abyssinian Banana).}

Differs from the two preceding varieties in having only one stem and not producing new shoots from the base. The largest as well as perhaps the oldest known variety. Stem often 12 to $20 \mathrm{ft}$. high and 18 inches in diameter, with enormous leaves $\mathrm{I} 2$ to $\mathrm{I} 5 \mathrm{ft}$. long and $\mathrm{I} \frac{1}{2}$ to $2 \mathrm{ft}$. wide. Unexcelled for tropical effect.

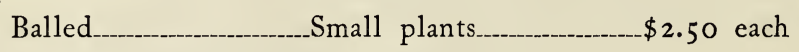

Salvia leucantha (Purple Sage) Mexico.

Shrubby perennial, $\mathrm{I} \frac{1}{2}$ to $2 \mathrm{ft}$. high with dense, woolly, sage-like foliage. Flowers are borne on erect stems a foot or more in height, of a deep purplish color. Useful for foundation planting, as it blooms until late fall.

$$
\text { Balled________ \$ } .50 \text { each }
$$

Salvia farinacea (Blue Sage) Texas.

Similar to Leucantha but larger and looser in growth. Very showy when in bloom; of a pleasing blue color.

Balled Strong plants $\$ .50$ each

\section{Grasses and Yuccas}

\section{Bocconia cordata (Plume Poppy) China.}

A tall-growing, herbaceous perennial, reaching 8 to $\mathrm{I}$ o $\mathrm{ft}$. in height. Strik- . ing foliage, large and many-lobed, heart-shaped leaves of a light green color. The small, poppy-like flowers without petals are borne in large, feathery or plume-like masses in terminal panicles raised high above the foliage, and make a bold, striking effect in shrubbery and background planting.

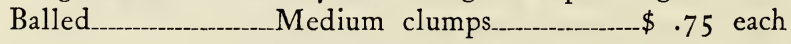

\section{Cyperus alternifolius (Umbrella Sedge) Madagascar.}

A grass-like perennial, 2 to $4 \mathrm{ft}$. in height. Curious, grass-like flowers are borne in clusters on stems 2 to $3 \mathrm{ft}$. high, surrounded by grass-like leaves 8 to I 2 inches long and $\frac{1}{2}$ inch wide, shaped like a many-ribbed umbrella. Excellent for aquatic effects, as it grows well with its roots partly or even wholly submerged.

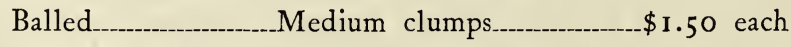

\section{Cyperus papyrus (Egyptian Paper Plant) Egypt.}

This is the plant from which the famous Egyptian paper is made. One of our most striking and beautiful subjects for water effects. Growing to a height of $\mathbf{I} 0$ to $\mathbf{I} 2 \mathrm{ft}$. with stems 2 inches and more in diameter, with flowering heads often $3 \mathrm{ft}$. across. Can be planted in soil where roots reach into the water or planted in boxes entirely submerged.

Balled Medium clumps $\$ 1.50$ each 


\section{Cynbopogon citratus (Lemon Grass, Citronella Oil Plant) Trop- ical Asia.}

Ornamental grass with aromatic properties from which oil of Citronella is produced. Grows 2 to $3 \mathrm{ft}$. high and is useful for foreground planting.
Balled
Medium clumps.
$\$ .75$ each

Miscanthus sinensis gracillimus (Maiden Grass) Tropical Asia.

Tall, perennial, ornamental grass with leaves long and narrow, $\frac{1}{4}$ inch wide and $4 \mathrm{ft}$. in height, and where grown as individual specimens makes clumps $; \mathrm{ft}$. in diameter. Its long, tassel-like flowers, whitish in color, are very effective in borders or as individual specimens.

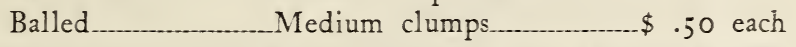

Miscanthus sinensis zebrinus (Zebra Grass) Tropical Asia.

A larger leaved variety having zebra-like yellow stripes, the entire length of the leaf. A very pleasing contrast to the foregoing.

Balled__._._. \$ . 50 each

Ophiopogon japonicus (Snakebeard) Japan.

Ornamental perennial, stemless grass, with dark green leaves 6 to 8 inches long and less than $\frac{1}{2}$ inch wide. Much used for border edging. It needs no clipping and makes a dark green, excellent ground cover under trees where practically nothing else will grow.
Balled
Medium clumps.
$\$ .50$ each

\section{Thalia dealbata (Bog Plant) Southern States.}

A stately, aquatic perennial, having large, long-stemmed, Canna-like leaves I to $2 \mathrm{ft}$. long. Interesting flowers are borne in pairs on erect stems, often 10 $\mathrm{ft}$. high, blue in color. Should be planted in shallow water or in wet soil.

$$
\text { Balled__._._. } \$ 1.50 \text { each }
$$

Vitiveria zizanoides (Vetivere) E. Indies.

Aromatic, perennial, ornamental grass with long panicles of numerous slender racemes. It has very aromatic rhizomous roots, much used in medicines and perfumes from prehistoric times. Excellent for border plantings.

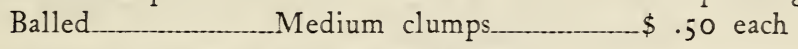

Yucca aloifolia (Spanish Dagger) Mexico.

Striking desert plants with dagger-like foliage, growing almost horizontally from a stiff stem 3 to $4 \mathrm{ft}$. in height. Leaves are dark green with a brownish tinge; 6 to 9 inches long and $\mathrm{I} \frac{1}{4}$ to $\mathrm{I} \frac{1}{2}$ inches wide, and a sharp, strong spike at the ends of the leaves. Flowers are borne on strong, erect spikes, 3 to $4 \mathrm{ft}$. long, and covered with white, lily-like, drooping flowers. Excellent subject for tropical effects and useful for vases, etc.

$$
\text { Balled _ } \quad 2 \text { yr. old plants____- \$1.00 each }
$$

Yucca aloifolia variegata. Mexico.

A variety of aloifolia, with larger leaves and a yellowish white stripe down the center. A very fine and striking variety.

$$
\text { Balled__ } 2 \text { yr. old plants___ \$1.50 each }
$$

Yucca filamentosa (Bear Grass) Southern States.

A variety having very little stem and long, green, arching leares I to $I \frac{1}{2}$ ft. long and $\mathrm{I}$ to $\mathrm{I} \frac{1}{2}$ inches wide. Fine, thread-like hairs are borne on the edges of the leaves and the spines are less formidable than aloifolia.

$$
\text { Balled. }
$$
2 yr. old plants. $\$ 1.00$ each 


\section{Yucca latifolia. Southern States.}

Perhaps the most attractive of all the Yuccas. Leaves are larger than the other varieties, 2 to $2 \frac{1}{2} \mathrm{ft}$. long, drooping, and 2 to $2 \frac{1}{2}$ inches wide. Flowers are bolder and very attractive, spikes reaching 4 to $5 \mathrm{ft}$. in height. Splendid variety for bold effects, either in beds or foreground planting.

Balled. 2 yr. old plants $\$ 1.25$ each

\section{Citrus Fruits}

Orange. Jungle Gardens Hybrid.

A variety originated by E. A. McIlhenny at Avery Island, Louisiana, by crossing the Louisiana Sweet on the Washington Naval. This orange is large, delightfully flavored, and as hardy as satsumas. The fruit has taken first premiums wherever shown.

Balled. Bearing trees $\$ 1.50$ each

\section{Fortunella margarita (Kumquat) Japan.}

Evergreen shrub or small ${ }^{-}$tree dense in growth and much-branched, reaching 8 to $\mathrm{ro} \mathrm{ft}$. in height. Foliage bright, glossy green, leaves $1 \frac{1}{2}$ to 2 inches long and $\frac{1}{2}$ to $\mathrm{I}$ inch wide. Flowers resembling an orange flower and very fragrant. Fruit is like a miniature orange and is useful for the making of marmalade and crystallized fruits. A well-grown specimen is a gorgeous sight when in full fruit; should be planted in a sheltered and sunny position. Round fruited and oblong fruited.

Balled. 6 yr. old bearing trees. $\$ 10.00$ each Small bearing trees $\$ 1.25$ each

\section{Roses}

We offer only the varieties that bloom every month in which there is no frost, and are best adapted for the South.

Captain Christy.

Beautiful peach blow pink, darker center, large and full. Good grower, free bloomer.

Bare root__Large 2 yr. old bushes___ $\quad .50$ each
Balled \& Burlapped__Large 2 yr. old bushes__\$ $\$ .75$ each

Columbia.

Light pink, deepening as bud opens, color becoming more intense until full maturity; deliciously fragrant; good but not strong grower.

Bare root___Large 2 yr. old bushes____ \$ .50 each

Balled \& Burlapped__LLarge 2 yr. old bushes._. $\$ .75$ each

Francis Scott Key. grower.

Bright crimson, a big rose with broad, curled petals, a vigorous upright

Bare root__________ $\$ .50$ each

Balled \& Burlapped___Large 2 yr. old bushes___ $\$ .75$ each 


\section{Frau Karl Druschki.}

The best white rose; flowers immense and very double, continuous bloomer; a strong grower.

Bare root_____._Large 2 yr. old bushes____.__._\$ .50 each

Balled \& Burlapped._Large 2 yr. old bushes_._\$ .75 each

General Jacqueminot.

Bright crimson; a profuse bloomer, medium grower.

Bare root__Large 2 yr. old bushes____ \$ .50 each

Balled \& Burlapped Large 2 yr. old bushes_.\$.75 each

General MacArthur.

Scarlet crimson. Large, double, very fragrant flowers. Very strong grower.

Bare root__Large 2 yr. old bushes___ \$ .50 each

Balled \& Burlapped_Large 2 yr. old bushes_\$ .75 each

Gruss an Teplitz.

Vivid red, one of the most vigorous of all roses, a strong, healthy grower, and ever bloomer with a delightful perfume.

Bare root__Large $2 \mathrm{yr}$. old bushes____ \$ \$ .50 each

Balled \& Burlapped Large 2 yr. old bushes_ $\$ .75$ each

Jonkheer J. L. Mock.

Clear pink. Very fragrant, extremely strong, vigorous grower, blooms with greatest freedom.

Bare root_Large $2 \mathrm{yr}$. old bushes___ $\$ .50$ each

Balled \& Burlapped Large 2 yr. old bushes_\$.75 each

Kaiserin Augusta Victoria.

Creamy white to primrose; very large, double; buds large and pointed. Foliage very fine; best white rose for the South.
Bare root
Large 2 yr. old bushes $\$ .50$ each

Balled \& Burlapped Large 2 yr. old bushes_ $\$ .75$ each

Lady Hillingdon.

Deep, apricot-yellow, lovely bud, semi-double when open. Slight fragrance. A vigorous grower, free bloomer.

Bare root__Large 2 yr. old bushes_____ \$ .50 each

Balled \& Burlapped_._Large 2 yr. old bushes__ $\$ .75$ each

Luxemburg.

Salmon rose, very distinctive. A free bloomer and vigorous grower.

Bare root__Large $2 \mathrm{yr}$. old bushes___ \$ .50 each

Balled \& Burlapped_Large $2 \mathrm{yr}$. old bushes_ $\$ .75$ each

Madame Caroline Testout.

Bright rose pink, flowers large size, very fragrant. A medium grower and abundant bloomer.

Bare root___Large 2 yr. old bushes____ \$ .50 each

Balled \& Burlapped_._Large 2 yr. old bushes__ $\$ .75$ each

Mrs. B. R. Cant.

Deep rose, with silvery center, very strong grower with large foliage and flowers.

Bare root____Large 2 yr. old bushes____ \$ .50 each

Balled \& Burlapped _L_Large 2 yr. old bushes_ $\$ .75$ each 
Ophelia.

Bright salmon, tipped rose on outer edge of petals, very fragrant, good grower. Flowers almost always perfect.

Bare root____ Large $2 \mathrm{yr}$. old bushes_____ \$ .50 each

Balled \& Burlapped___LLarge $2 \mathrm{yr}$. old bushes_._. $\$ .75$ each

Paul Neyron.

Rose to imperial pink, extremely large, fine form, delightfully fragrant. Very tall, vigorous grower, continuous bloomer, very few to no thorns.

Bare root___Large $2 \mathrm{yr}$. old bushes___ \$ .50 each

Balled \& Burlapped_._._Large 2 yr. old bushes___ $\$ .75$ each

Premier.

Rich, dark pink, full, good form, fragrant, good grower.

Bare root____ Large $2 \mathrm{yr}$. old bushes____ \$ .50 each

Balled \& Burlapped___Large $2 \mathrm{yr}$. old bushes..._\$ .75 each

Radiance (Pink).

Dark salmon-pink to silver flesh, open flowers, somewhat cupped. Lasts well, very fragrant. Remarkably strong grower, ever-bloomer.

Bare root_____Large $2 \mathrm{yr}$. old bushes____ \$ .50 each

Balled \& Burlapped___Large 2 yr. old bushes... $\$ .75$ each

Radiance (Red).

A splendid, even shade of clear red and of good cupped form, vigorous grower, ever-bloomer.

Bare root____Large $2 \mathrm{yr}$. old bushes_____ \$ .50 each

Balled \& Burlapped___Large 2 yr. old bushes..._\$ $\$ 75$ each

Ulrich Brunner.

Cherry red, profuse bloomer, very fragrant, fair grower.

Bare root____ Large 2 yr. old bushes____ \$ .50 each

Balled \& Burlapped___Large 2 yr. old bushes__- \$ .75 each

\section{Climbing Roses}

Climbing Black Prince.

Deep, velvety crimson, shaded blackish maroon, overlaying fiery scarlet blooms, large semi-double on long, stiff stems. A splendid rose.

Bare root_____Large $2 \mathrm{yr}$. old bushes____ \$ .50 each

Balled \& Burlapped___Large 2 yr. old bushes_._ $\$ .75$ each

Climbing Columbia.

Light pink, deepening as bud opens, becoming more intense until full maturity, deliciously fragrant, good but not very strong grower.

Bare root__ Large $2 \mathrm{yr}$. old bushes____ \$ .50 each

Balled \& Burlapped___Large 2 yr. old bushes___ $\$ .75$ each

Climbing Kaiserin Augusta Victoria.

Creamy white to primrose, very large double, buds large and pointed. Foliage very fine. Best white climbing rose for the South.

Bare root_____Large $2 \mathrm{yr}$. old bushes._-___ \$ .50 each

Balled \& Burlapped._._Large 2 yr. old bushes._._\$ .75 each 
Climbing Marechal Niel.

Deep chrome yellow, climbs to a great height and blooms in great profusion. No better climbing rose.
Bare roo Large $2 \mathrm{yr}$. old bushes $\$ .50$ each
Balled \& Burlapped _Large 2 yr. old bushes $\$ .75$ each

\section{Peaches}

We carry only the peaches that are especially raluable for home and market growing in the South.

Alexander.

Habit round, compact, foliage thick, leaves medium. Blooms middle to late March, ripens early June. Fruit medium, globular, greenish white with red cheek, a heavy bearer, quality medium, but valuable on account of its earliness; semi-cling.

$$
\text { Bare root } \quad-3-5 \mathrm{ft}
$$

\section{Chinese Cling.}

Habit low and spreading with dense foliage, leaves large. Blooms middle to late Marçh; fruit ripens middle July. Very large, globular, very juicy, skin creamy white, clingstone. Quality best.
Bare root $3-5 \mathrm{ft}$. $\$ .50$ each

\section{Early Crawford.}

Habit open, growth vigorous, leares large. Blooms middle to late March, ripens middle July. Fruit large, globular, bright yellow orerspread with red. Flesh lemon yellow, free stone, quality good, an enormous bearer.

\section{Elberta.}

$$
\text { Bare root } 3-5 \mathrm{ft} \text {. } \$ .50 \text { each }
$$

Habit open, spreading, growth vigorous, leaves large. Blooms middle March, ripens middle July. Fruit very large, free stone, bright yellow with red cheek, quality fair, an enormous producer, good shipper.

\section{Sneed.}

$$
\text { Bare root _ } 3-j \mathrm{ft} \text {.__ \$ } .50 \text { each }
$$

Habit low spreading, foliage dense, leaves large. Blooms middle to late March. Ripens early June. Fruit white, highly colored red, a heary bearer, quality good, semi-cling.

$$
\text { Bare root _ \$ } \$ .50 \text { each }
$$

\section{Triumph.}

Habit tall, open, very vigorous. Blooms middle March. Flowers red, ripens middle June, fruit medium, rusty red, flesh yellow, semi-cling, quality fair, an enormous producer.
Bare root $3-5 \mathrm{ft}$. $\$ . ; 0$ each

\section{Plums}

We offer only those best adapted for the Southern garden.

\section{Burbank.}

Tree vigorous grower, upright branches. Fruit large, dark red mottled over yellow, flesh deep yellow, firm and juicy. 


\section{Kelsey.}

Tree strong grower, bearing while young heavy crops of large greenish yellow fruit, flushed with red. Flavor fine, juicy.
Bare root $-4-5 \mathrm{ft}$. $\$ .50$ each

\section{Satsuma.}

Tree upright grower of medium size. Fruit large, dull red with greenish dots, quality good; a splendid keeper and good shipper.

\section{Terrel.}

$$
\text { Bare root__ } \quad \text { \$ } .50 \text { each }
$$

A strong, healthy grower, fruit large, reddish yellow mottled with wine color when full ripe, firm and juicy, one of the finest for the extreme South. Bare root $4-5 \mathrm{ft}$. $\$ .50$ each

\section{Pears} South.

We offer only two, as these are the only sure croppers of merit in the Keifer.

A vigorous grower, bearing enormous crops of large yellow fruit, with vermilion cheek, the best of all pears for cooking and canning.
Bare root
$4-5 \mathrm{ft}$.
$\$ .50$ each

Garber.

A vigorous grower, fruit resembling the Keifer, but much earlier and quality better for the table.
Bare root
$-4-5 \mathrm{ft}$.
$\$ .50$ each

\section{Pecans}

We offer four of the large paper shell varieties that over a long test have proved the heaviest bearers, the best table and best market varieties. We have found trees 4 to $5 \mathrm{ft}$. size the most economical, and surest growers.

Stuart.

A vigorous, upright grower, bearing heavy crops of large, full-meated nuts of excellent quality.

\section{Success.}

Bare root $\$$ - 4 - 25 each

Tree rapid grower, regular and heavy bearer, nuts large, thin shell, crack well. None better.
Bare root $4-5 \mathrm{ft}$. $\$ 1.25$ each

\section{Moneymaker.}

A vigorous, upright grower, nuts of good size, round and easily cracked. Kernel full, rich, a splendid bearer and does well on any land.
Bare root $4-5 \mathrm{ft}$
$\$ 1.25$ each

Schley.

A good, upright grower, bearing a great abundance of medium sized nuts, of unsurpassed quality.

Bare root__ $\$ 1.25$ each 


\section{INDEX}

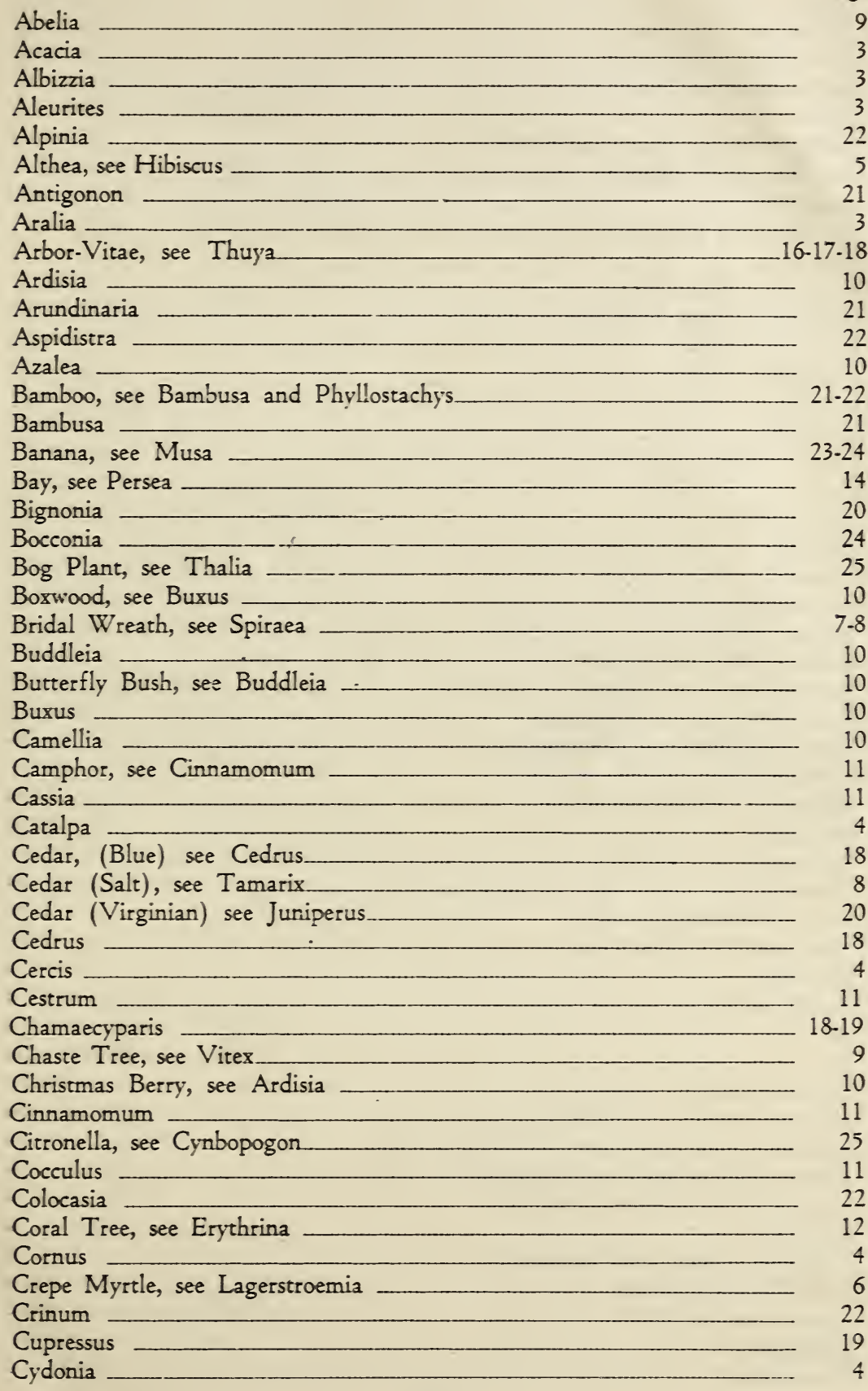




\section{INDEX-Continued}

Cyperus

Cypresś, see Cupressus

Cynbopogon

Daubentonia, see Sesbania

Deutzia

Devil's Walking Stick, see Aralia

Diervilla, see Weigelia

Diospyros

Dogwood, see Cornus

Elaeagnus

Elder, see Sambucus

Elephant Ear, see Colocasia

Elm, see Ulmus _-________- 8-9

Eriobotrya _-

Erythrina -1_-

Escallonia _-__-

Fatsia - - - - - 12

Ficus -1-

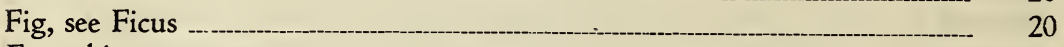

Forsythia -

Fortunella, see Kumquat ___ 26

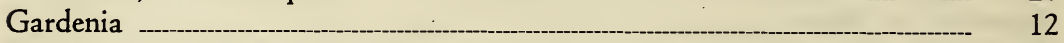

Ginger Shell Flower, see Alpinia

Golden Bells, see Forsythia

Grass (Bear), see Yucca _.___________- 25

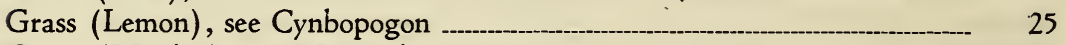

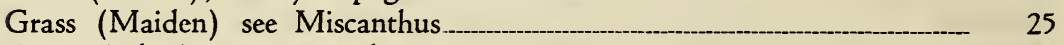

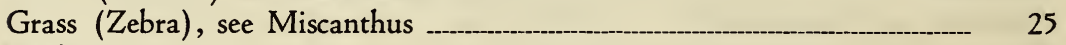

Hedera - _-_ 20

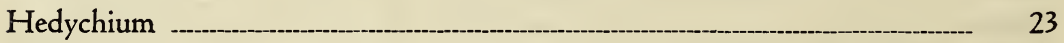

Hibiscus - _-_ 5

Hemerocallis

Holly (American) see Ilex -12

Honeysuckle, see Lonicera _-__

Hydrangea . .__ _ _ 5

Hypericum - -

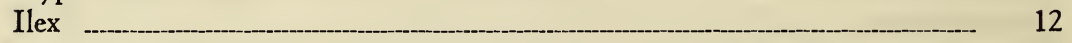

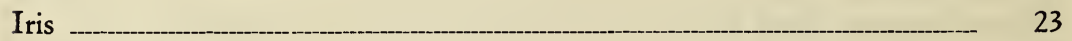

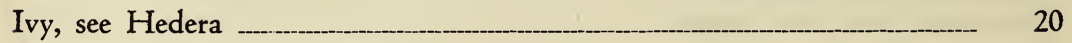

Jasmine (cape) see Gardenia _-_ _- 12

Jasmine (confederate) see Trachelospermum _.____ 21

Jasmine (Primrose), see Jasminum ___ _ _ _ _ 13

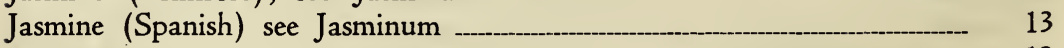

Jasminum ________________ 13

Jerusalem Thorn, see Parkinsonia _____________ 6

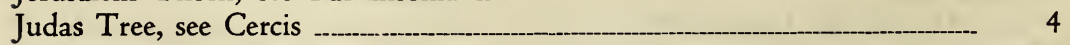

Juniper, see Juniperus

Juniperus ___

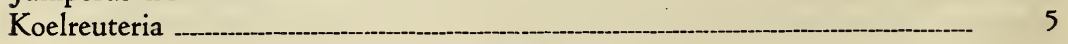


INDEX-Continued

Kumquat 26

Lagerstroemia _- 6

Lantana ___ 23

Laurel (Cherry), see Prunus___ 15

$\begin{array}{ll}\text { Laurustinus, see Viburnum ___ } & 16\end{array}$

Ligustrum _- 13

Lily (Day) see Hemerocallis ___ 23

Lily (Ginger), see Hedychium ___ 23

Lily (Milk and Wine), see Crinum ___ 22

Liriodendron —u 6

Lonicera —__ 20

Loquat, see Eriobotrya __________ 11

Magnolia ___ 13

Mahonia —_ 14

Mallow, see Hibiscus ___ 5

Malvaviscus _- 14

Mimosa, see Albizzia ___ 3

Miscanthus ___ 25

Mock Orange, see Philadelphus ___ 6

Musa 23.24

Myrtle, see Myrtus ___ 14

Myrtus __ 14

Nandina —_- 14

Nerium —__ 14

Oak, see Quercus ___ 16

Oleander, see Nerium ___ 14

Orange _ـ_____ 26

Oregon Grape, see Mahonia ___________ 14

Ophiopogon —__ 25

Paper Plant (Chinese) see Fatsia ___ 12

Paper Plant (Egyptian), see Cyperus __ 24

Parkinsonia __ 6

Peaches —_- 29

Pears - 30

Pecans ___ 30

Persea —_ 14

Persimmon, see Diospyros _—_ $\quad 4-5$

Philadelphus ___ 6

Photinia $6-15$

Phyllostachys ___ 22

Pine, see Pinus _ 20

Pinus

Pittosporum —__ 15

Plumbago —__ 15

Plums 29-30

Podocarpus ___ _ _ _ _ 15

Pomegranate, see Punica $\square \square-\square$

Poplar, see Populus _ 6-7

Populus $6-7$ 


\section{INDEX-Continued}

Poppy (Plume), see Bocconia

Privet, see Ligustrum ___ 13

Prunus _-1_ 15

Punica ___ 7

Queen of the Night, see Cestrum _____________ 11

Quercus _____ 16

Quince (Japanese Flowering), see Cydonia _ _ _ _ _ _ _ _ 4

Redbud, see Cercis __________ 4

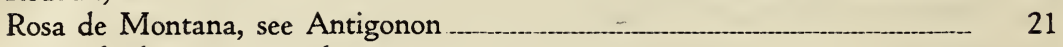

Rose of Sharon, see Hibiscus ___ 5

Roses _-_ $\quad 26$

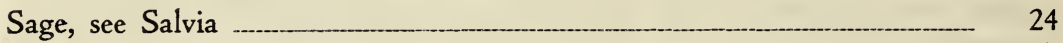

Salix

Salvia _-___ 24

Sambucus _-_ _ _ _ _ _ _ -

Sapium -1_ _ _ _ -

Sedge (Umbrella), see Cyperus _-_ - $\square-\square-14$

Senna (Flowering), see Cassia ____________________________ 11

Serissa - 16

Sesbania _____ 7

Snakebeard, see Ophiopogon _.____________ 25

Snowberry, see Synphoricarpus _.__________ 8

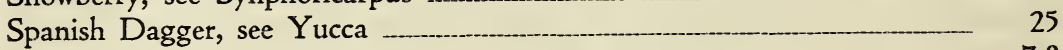

Spiraea ___

Sterculia

St. John's Wort, see Hypericum __________ 5

Synphoricarpus ___

Syringa, see Philadelphus ______________ 6

Tallow Tree, see Sapium ___

Tamarix ㄴ.

Thalia _- 25

Thuya $16-17-18$

Trachelospermum ____________ 21

Trumpet Creeper, see Bignonia ______ 20

Tulip Tree, see Liriodendron _..__ 6

Tung-oil Tree, see Aleurites _.___._._._._. 3

Turk's Cap, see Malvaviscus ____________ 14

Ulmus _.__ 8-9

Varnish Tree, see Sterculia ___

Vetevere, see Viteveria _____________ 25

Viburnum 16

Vitex 9

Viteveria 25

Weigelia $\quad 9$

$\begin{array}{lr}\text { Weigelia } & 7 \\ \text { Willow, see Salix } \quad-\quad & 21\end{array}$

Wisteria _-_.

Yaupon, see Ilex _a

Yew (Japanese) see Podocarpus ___ $25-26$

Yucca 


